\title{
PENDEKATAN KOMUNIKATIF DALAM PEMBELAJARAN BAHASA INDONESIA UNTUK MENINGKATKAN KETERAMPILAN BERBICARA SISWA DI KELAS IV SD
}

\author{
Asiah \\ SDN Jatiroke I Jatinangor \\ J. Letda Lukito No. 56 Jatinangor Sumedang \\ Email: asiahaja42@yahoo.com
}

\begin{tabular}{|c|c|}
\hline ABSTRACT & ABSTRAK \\
\hline $\begin{array}{l}\text { This research aims to improve students' skills in } \\
\text { speaking. Researchers apply a communicative } \\
\text { approach through classroom action research. } \\
\text { Based on the results of research, learning } \\
\text { Indonesian with the application of } \\
\text { communicative approach showed an increase } \\
\text { in the students' speaking skills class IV SDN } \\
\text { Jatiroke I both orally and in writing. This increase } \\
\text { can be seen from the observation and } \\
\text { implementation of corrective actions at each } \\
\text { cycle. First cycle that scored above } 60 \text { KKM there } \\
\text { are } 16 \text { students (61.53\%) with an average grade } \\
62.30 \text { increase significantly in the second cycle to } \\
25 \text { students ( } 96.15 \% \text { ) with an average grade of } \\
80 \text {. } \\
\text { Keywords: approach, communicative skills, } \\
\text { speaking, elementary school students. }\end{array}$ & $\begin{array}{l}\text { Penelitian ini bertujuan untuk meningkatkan } \\
\text { keterampilan siswa dalam berbicara. Peneliti } \\
\text { menerapkan pendekatan komunikatif melalui } \\
\text { metode penelitian tindakan kelas. Berdasarkan } \\
\text { hasil penelitian, pembelajaran Bahasa Indonesia } \\
\text { dengan penerapan pendekatan komunikatif } \\
\text { menunjukkan adanya peningkatan dalam } \\
\text { keterampilan berbicara siswa kelas IV SDN } \\
\text { Jatiroke I baik secara lisan maupun tulisan. } \\
\text { Peningkatan ini dapat dilihat dari hasil observasi } \\
\text { dan pelaksanaan tindakan perbaikan pada } \\
\text { setiap siklusnya. Siklus I yang mendapat nilai di } \\
\text { atas Kriteria Ketuntasan Minimal (KKM) sebesar } 60 \\
\text { ada } 16 \text { siswa (61,53\%) dengan rata-rata kelas } \\
62,30 \text { meningkat secara signifikan di siklus II } \\
\text { menjadi } 25 \text { siswa (96,15\%) dengan rata-rata kelas } \\
80 \text {. } \\
\text { Kata kunci: pendekatan, komunikatif, } \\
\text { keterampilan berbicara, siswa SD. }\end{array}$ \\
\hline
\end{tabular}

How to Cite: Asiah, A. (2015). PENDEKATAN KOMUNIKATIF DALAM PEMBELAJARAN BAHASA INDONESIA UNTUK MENINGKATKAN KETERAMPILAN BERBICARA SISWA DI KELAS IV SD. Mimbar Sekolah Dasar, 2(1), 21-35. doi:http://dx.doi.org/10.17509/mimbar-sd.v2i1.1319.

PENDAHULUAN Pendidikan merupakan salah satu upaya dalam rangka mencerdasakan kehidupan bangsa sebagaimana diamanatkan dalam Pasal 31 dan Konstitusi Bangsa Indonesia yaitu Undang-Undang Dasar 1945. Selain itu, pendidikan merupakan salah satu bentuk perwujudan kebudayaan manusia yang dinamis dan berkembang. Dinamisasi dan perkembangan pendidikan sejalan dengan perubahan daya nalar dan daya pikir manusia itu sendiri. Perubahan itu harus berlangsung dan terus terbaharui, untuk meningkatkan kualitas masyarakat pada umumnya.

Perubahan KTSP yang beragam mengacu pada standar nasional pendidikan untuk menjadi pencapaian tujuan pendidikan nasional. Implementasi Undang-Undang Republik Indonesia Nomor 20 Tahun 2003 tentang Sistem Pendidikan Nasional dijabarkan ke dalam sejumlah peraturan antara lain Peraturan Pemerintah Nomor 
Asiah, Pendekatan Komunikatif dalam Pembelajaran Bahasa...

19 Tahun 2005 tentang Standar Nasional Pendidikan. Peraturan pemerintah ini memberikan arahan tentang perlunya disusun dan dilaksanakan delapan standar nasional pendidikan, yaitu Standar Isi, Standar proses, Standar Kompetensi Lulusan, Standar Pendidikan dan Tenaga Kependidikan, Standar Sarana dan Prasarana, Standar Pengelolaan, Standar Pembiayaan, dan Standar Penilaian Pendidik.

Bahasa memiliki peran sentral dalam perkembangan intelektual, sosial, dan emosional peserta didik dan merupakan penunjang keberhasilan dalam mempelajari semua bidang studi. Pembelajaran Bahasa Indonesia diarahkan untuk meningkatkan kemampuan peserta didik untuk berkomunikasi dalam bahasa Indonesia dengan baik dan benar, baik bicara lisan maupun tulis, serta menumbuhkan apresiasi hasil karya kesusastraan manusia Indonesia.

Seseorang dapat membaca atau menulis secara mandiri, dapat menyimak siaran radio sendiri. Akan tetapi, sangatlah jarang orang melakukan kegiatan berbicara tanpa hadirnya orang kedua sebagai pemerhati atau penyimak. Oleh karena itu, Valette (1977) berpendapat bahwa berbicara merupakan suatu kemampuan berbahasa yang bersifat sosial. Kemudian menurut Solchan, dkk. (2001, p. 6.41), "Pendekatan komunikatif dalam pembelajaran bahasa sering diasosiasikan dengan silabus. Pemilihan materi silabus itu sendiri tidak didasarkan pada tingkat kesukaran dan kerumitan butir struktur, tetapi didasarkan pada kebutuhan pembelajar. Oleh karena itu, analisis kebutuhan merupakan kebutuhan yang mutlak".

Atas dasar pemahaman tersebut, penulis merasa ada kekurangan dalam pembelajaran Bahasa Indonesia di kelas IV di SDN Jatiroke I, dilihat dari hasil evaluasi dan sikap siswa belum mencapai hasil yang optimal terutama dalam berbicara cara menyampaikan pesan yang diterima melalui telepon sesuai dengan isi pesan serta tidak sesuai dengan situasi dan konteks. Berdasarkan hasil identifikasi masalah, dapat ditemukan pula bahwa siswa kurang responsip dalam memberi tanggapan terhadap materi; siswa kurang aktif dan merasa takut untuk tampil di depan kelas; siswa kurang terampil berbicara dalam menyampaikan kembali pesan yang diterima dengan lafal dan intonasi yang tepat; siswa kurang fasih dalam melafalkan kata-kata bahasa Indonesia; dan sebagian siswa belum mendapat pertanyaan yang diberikan guru.

Apabila kondisi seperti itu terus dibiarkan akan berpengaruh terhadap proses pembelajaran yang mengakibatkan semakin rendahnya keterampilan berbicara siswa kelas IV SDN Jatiroke I, sehingga perlu adanya inovasi dalam pembelajaran yang bertujuan untuk 
mencapai tujuan pembelajaran yaitu siswa mampu meningkatkan keterampilan berbicara dalam menyampaikan pesan yang diterima melalui telepon sesuai dengan isi pesan, lafal dan intonasi yang tepat.

Berdasarkan latar belakang di atas, penulis bermaksud mengadakan perbaikan praktik pembelajaran melalui penelitian tindakan kelas (PTK) dengan penggunaan pendekatan komunikatif dengan mengacu pada rumusan masalah: apakah pendekatan komunikatif dalam pembelajaran Bahasa Indonesia dapat meningkatkan keterampilan berbicara siswa kelas IV SDN Jatiroke I?

\section{Pembelajaran Komunikatif}

Pendekatan komunikatif adalah suatu pendekatan yang bertujuan untuk membuat kompetensi komunikatif sebagai tujuan pembelajaran bahasa, juga mengembangkan prosedur-prosedur bagipembelajaran empat keterampilan berbahasa (menyimak, membaca, berbicara dan menulis), mengakui dan menghargai saling ketergantungan bahasa. Ciri-ciri utama pendekatan komunikatif adalah adanya dua kegiatan yang saling berkaitan erat, yakni:

1. Kegiatan-kegiatan komunikasi fungsional (functional communication activities) yang terdiri atas empat hal, yakni mengolah informasi, berbagai dan mengolah informasi, berbagi informasi dengan kerjasama terbatas, dan berbagi informasi dengan kerjasama tak terbatas.

2. Kegiatan interaksi sosial (social interaction activities) terdiri atas enam hal, yaikni improvisasi, lakon-lakon pendek yang lucu, aneka simulasi, dialog dan bermain peran, sidangsidang konversasi dan diskusi, serta berdebat.

\section{Aspek-Aspek yang Berkaitan Erat dengan Pendekatan Komunikatif}

Delapan aspek yang berkaitan erat dengan pendekatan komunikatif (Nunan dalam Solchan, dkk., 2001, p. 6.6) akan dipaparkan sebagai berikut.

Tabel 1. Aspek yang berkaitan dengan Pendekatan Komunikatif

\begin{tabular}{|c|c|c|}
\hline No. & $\begin{array}{l}\text { Aspek } \\
\text { yang } \\
\text { Berkaitan }\end{array}$ & $\begin{array}{l}\text { Kebermaknaan dalam } \\
\text { Pendekatan Komunikatif }\end{array}$ \\
\hline 1. & $\begin{array}{l}\text { Teori } \\
\text { Bahasa }\end{array}$ & $\begin{array}{l}\text { Pendekatan komunikatif } \\
\text { berdasarkan teori bahasa } \\
\text { menyatakan bahwa pada } \\
\text { hakikatnyar bahasa } \\
\text { adalah suatu sistem untuk } \\
\text { mengekspresikan makna, } \\
\text { yang menekankan pada } \\
\text { dimensi semantik dan } \\
\text { komunikatif daripada ciri- } \\
\text { ciri gramatikal bahasa. } \\
\text { Oleh karena itu, yang } \\
\text { perlu ditonjolkan adalah } \\
\text { interaksi dan komunikasi } \\
\text { bahasa, bukan } \\
\text { pengetahuan tentang } \\
\text { bahasa. }\end{array}$ \\
\hline 2. & $\begin{array}{l}\text { Teori } \\
\text { Belajar }\end{array}$ & $\begin{array}{lr}\text { Teori belajar yang } & \text { cocok } \\
\text { untuk pendekatan ini } \\
\text { adalah teori pemerolehan } \\
\text { bahasa kedua secara } \\
\text { ilmiah. Teor } & \text { ini } \\
\text { beranggapan } & \text { bahwa } \\
\text { proses belajar lebih efektif } \\
\text { apabila bahasa diajarkan } \\
\text { secara alamiah sehingga } \\
\text { proses belajar bahasa } \\
\text { yang lebih } r \text { efektif } \\
\text { dilakukan } & \text { melalui }\end{array}$ \\
\hline
\end{tabular}




\begin{tabular}{|c|c|c|}
\hline & & $\begin{array}{l}\text { komunikasi langsung } \\
\text { dalam bahasa yang } \\
\text { dipelajari. }\end{array}$ \\
\hline 3. & Tujuan & $\begin{array}{l}\text { Kebutuhan siswa yang } \\
\text { utama dalam belajar } \\
\text { bahasa berkaitan dengan } \\
\text { kebutuhan berkomunikasi } \\
\text { maka tujuan umum } \\
\text { pembelajaran bahasa } \\
\text { adalah mengembangkan } \\
\text { kemampuan siswa untuk } \\
\text { berkomunikasi } \\
\text { (kompetensi dan } \\
\text { performasi komunikatif). }\end{array}$ \\
\hline 4. & Silabus & $\begin{array}{l}\text { Silabus harus disusun } \\
\text { searah dengan tujuan } \\
\text { pembelajaran dan tujuan- } \\
\text { tujuan yang dirumuskan } \\
\text { dan materi-materi yang } \\
\text { dipilih harus sesuai dengan } \\
\text { kebutuhan siswa. }\end{array}$ \\
\hline 5. & $\begin{array}{l}\text { Tipe } \\
\text { Kegiatan }\end{array}$ & $\begin{array}{l}\text { Dalam pembelajaran } \\
\text { bahasa Indonesia dengan } \\
\text { pendekatan komunikatif, } \\
\text { pembelajaran dipajankan } \\
\text { pada situasi komunikasi } \\
\text { yang nyata, seperti tukar } \\
\text { menukar informasi, } \\
\text { negosiasi maka ata } \\
\text { kegiatan lain yang sifatnya } \\
\text { rill. }\end{array}$ \\
\hline 6. & $\begin{array}{l}\text { Peranan } \\
\text { Guru }\end{array}$ & $\begin{array}{l}\text { Dalam pembelajaran ini, } \\
\text { guru hanya berperan } \\
\text { sebagai fasilitas proses } \\
\text { komunikasi, partisipasi } \\
\text { tugas dan teks, } \\
\text { penganalisis kebutuhan, } \\
\text { konselor, dan manajer } \\
\text { proses belajar. }\end{array}$ \\
\hline 7. & $\begin{array}{l}\text { Peranan } \\
\text { Siswa }\end{array}$ & $\begin{array}{l}\text { Dalam pembelajaran ini, } \\
\text { pembelajar (baca: siswa) } \\
\text { berperan sebagai } \\
\text { pemberi dan penerima, } \\
\text { negosiator, dan interaktor } \\
\text { sehingga para siswa tidak } \\
\text { hanya menguasai bentuk- } \\
\text { bentuk bahasa, tetapi } \\
\text { juga bentuk dan } \\
\text { maknanya dalam } \\
\text { kaitannya dengan konteks } \\
\text { pemakaiannya. }\end{array}$ \\
\hline 8. & $\begin{array}{l}\text { Peranan } \\
\text { Materi }\end{array}$ & $\begin{array}{l}\text { Dalam pembelajaran ini, } \\
\text { materi harus disusun dan } \\
\text { disajikan dalam peranan } \\
\text { sebagai pendukung usaha } \\
\text { meningkatkan kemahiran } \\
\text { berbahasa dalam tindak } \\
\text { komunikasi nyata. }\end{array}$ \\
\hline
\end{tabular}

\section{Penerapan Pendekatan Komunikatif} dalam Pembelajaran Bahasa Indonesia
Pendekatan komunikatif merupakan pendekatan yang sangat tepat dalam pembelajaran Bahasa, termasuk Bahasa Indonesia. Ketepatan ini sangat berkaitan dengan pandangan-pandangan ilmu bahsa yang menggarisbawahi bahwa belajar bahasa pada intinya belajar berkomunikasi. Artinya, dalam proses tersebut pemakaian bahasa sesuai dengan fungsinya adalah hal yang sangat esensial dalam sebuah proses pembelajaran bahasa.

Berkaitan dengan kompetensi komunikatif ini, Canale \& Swain (dalam Solchan, dkk., 2006, p. 6.19) mengemukakan empat unsur yang berkaitan dengan kemampuan komunikasi, yakni:

1. kemampuan gramatika: kemampuan penutur menggunakan kaidah gramatika;

2. kemampuan sosiolinguistik: kemampuan penutur memahami konteks social tempat terjadinya komunikasi;

3. kemampuan wacana: kemampuan penutur menyampaikan maksudmaksud komunikasi secara koheren;

4. kemampuan strategi: kemampuan penutur menggunakan berbagai cara/strategi dalam berkomunikasi.

\section{METODE}

\section{Waktu Penelitian}

Waktu pelaksanaan penelitian dilakukan selama dua bulan. Jadwal pelaksanaan perbaikan pembelajaran antarsiklus dilakukan dengan jeda waktu satu 
minggu, yaitu pada setiap jadwal jam mata pelajarannya.

\section{Tempat Penelitian}

Penelitian bertempat di SDN Jatiroke I, Jalan Letda Lukito No. 56 Kecamatan Jatinangor Kabupaten Sumedang 45363 sebagai populasi sekaligus sempel penelitian adalah siswa kelas IV SDN Jatiroke I dengan jumlah siswa 26 orang yang terdiri atas 16 siswa laki-laki dan 10 siswa perempuan.

\section{Karakteristik}

Secara umum siswa yang bersekolah di SDN Jatiroke I Kecamatan Jatinangor Kabupaten Sumedang berlatar belakang ekonomi menengah ke bawah, dengan kondisi mata pencaharian dan latar belakang orang tua yang sangat beragam. Pada dasarnya siswa kelas IV mempunyai semangat belajar yang tinggi bila didukung dengan baik dan diberi kesempatan dengan penyajian pembelajaran yang maksimal. Dengan keragaman latar belakang itulah yang menjadi tantangan tersendiri bagi penulis untuk menggali dan berupaya terus memberikan perhatian khusus di dalam proses pembelajaran, sehingga dapat menghasilkan lulusan yang lebih bermutu dan berprestasi.

\section{Prosedur Penelitian}

Penelitian ini berupa penelitian tindakan kelas (PTK). Oleh sebab itu, prosedur penelitian pun mengikuti prosedur PTK yang sudah baku, dari mulai kegiatan perencanaan sampai kegiatan refleksi, dengan berdasarkan pada model tertentu.

Prosedur atau langkah-langkah penelitian yang dilakukan terbagi dalam bentuk siklus, kegiatan mengacu pada model yang diadopsi dari Kemmis \& Taggart (Wiriaatmadja, 2005; Wardani, 2006), di mana setiap siklus terdiri atas empat kegiatan pokok adalah kegiatan: perencanaan, tindakan pelaksanaan, observasi, dan refleksi. Empat kegiatan ini dilakukan secara simultan yang urutannya dapat mengalami modifikasi.

Desain penelitian tindakan kelas mengikuti desain model Kemmis \& Taggart (Wiriaatmadja, 2005; Wardani, 2006) sebagai berikut: Refleksi Awal $\rightarrow$ Perencanaan Tindakan I $\rightarrow$ Pelaksanaan Tindakan I $\rightarrow$ Observasi, Refleksi, dan Evaluasi I $\rightarrow$ Perencanaan Tindakan $\| \rightarrow$ Pelaksanaan Tindakan $\| \rightarrow$ Observasi, Refleksi dan Evaluasi II.

Berdasarkan desain di atas, tahapan penelitian tindakan kelas yang akan dilakukan mengadopsi pendapat Mulyasa (2009), dengan rincian materi pelajaran dikembangkan dari Febicahyanti, dkk. (2006) serta Warsidi \& Farika (2009).

dijelaskan sebagai berikut.

\section{Refleksi Awal}

Pada tahap ini dilakukan identifikasi masalah yakni kurang terampilnya berbicara siswa kelas IV dalam menyampaikan pesan yang diterima 
Asiah, Pendekatan Komunikatif dalam Pembelajaran Bahasa...

melalui telepon sesuai isi pesan lafal dan intonasi yang tepat.

\section{Perencanaan Tindakan}

Masalah yang ditemukan akan diatasi dengan melakukan langkah-langkah perencanaan tindakan, yaitu menyusun instrumen penelitian berupa: rencana pelaksanaan pembelajaran (RPP), lembar kegiatan siswa, soal tes, angket, dan lembar observasi.

\section{Pelaksanaan Tindakan}

Pada tahap ini dilakukan tindakan berup apelaksanaan kegiatan pembelajaran, pengumpulan data dari angket, lembar observasi dan tes.

\section{Observasi, Refleksi dan Evaluasi}

Tahap ini dilakukan untuk mengumpulkan data dan menganalisisnya. Selanjutnya dapat ditarik simpulan dari penelitian ini.

\section{HASIL}

Penelitian yang telah dilakukan penulis dari siklus I hingga siklus || selama dua bulan, dibantu oleh lima orang guru rekan sejawat yang bertindak sebagai observer dan berfungsi sebagai teman diskusi dalam tahap refleksi.

Berdasarkan deskripsi data awal, peneliti bersama-sama dengan praktisi menyusun rencana tindakan perbaikan untuk memecahkan kesulitan-kesulitan dalam berbicara siswa kelas IV SDN Jatiroke I. Peneliti dan praktisi sepakat untuk menggunakan pendekatan komunikatif dalam pembelajaran Bahasa Indonesia guna meningkatkan keterampilan berbicara siswa kelas IV SDN Jatiroke I.
Atas dasar kesepakatan itu maka disusun rencana perbaikan tindakan terhadap masalah-masalah yang dihadapi siswa dalam berbicara, langkah-langkah perencanaan tindakan itu mencakup menyusun instrumen penelitian berupa: rencana pelaksanaan pembelajaran (RPP), lembar kegiatan siswa, soal test, dan lembar observasi serta catatan hasil evaluasi. Berikut ini hasil tindakan perbaikan pembelajaran selama dua siklus.

\section{Siklus I}

\section{Deskripsi}

Kegiatan pembelajaran siklus I dilaksanakan selama 2 jam pelajaran yang dimulai dari pukul 07.00 sampai pukul 08.10. Kegiatan pembelajaran dihadiri 26 siswa, kompetensi dasar yang dipelajari berbicara. Menyampaikan pesan yang diterima melalui telepon sesuai dengan isi pesan dengan indikator menyampaikan pesan yang diterima melalui telepon sesuai dengan isi pesan, lafal dan intonasi yang tepat. Pembelajaran dimulai dengan tanya-jawab untuk menggali pengetahuan awal siswa. Pada kegiatan ini siswa terlihat ragu-ragu untuk menjawab pertanyaan yang diberikan guru, tidak ada satu pun siswa yang mengajukan pertanyaan.

Memasuki kegiatan inti, siswa melakukan percakapan secara berpasangan di depan kelas. Awalnya siswa terlihat malumalu dan kurang keberanian untuk tampil di depan kelas. Dalam pelaksanaan 
berbicara di depan kelas walau sudah diminta dengan jelas masih ada siswa yang kesulitan untuk berbicara dengan menggunakan bahasa indonesia karena bahasa yang digunakan sehari-hari adalah bahasa Sunda. Tahap selanjutnya pelaksanaan percakapan dengan bermain peran, siswa masih ada yang malu-malu dan kurang keberaniannya walaupun telah diberi motivasi oleh guru. Pada saat siswa yang ditunjuk guru untuk tampil ke depan situasi menjadi ribut, segera guru memberikan arahan dan aturan cara berbicara di depan kelas dengan benar. Selain itu, peneliti juga menjanjikan memberikan penghargaan kepada kelompok yang paling tertib dan disiplin dalam melaksanakan percakapan bermain peran dengan baik.

Pada tahap akhir pembelajaran peneliti mengadakan evaluasi untuk mengukur sejauh mana penguasaan materi yang telah diajarkan. Hambatan utama yang peneliti temukan pada tahap ini adalah adanya beberapa siswa yang masih kurang memahami pertanyaan dalam soal cerita yang ada dalam percakapan. Selain itu peneliti juga menemukan beberapa siswa yang masih bekerjasama bahkan mencontek pekerjaan temannya.

Berdasarkan hasil evaluasi akhir secara individu diperoleh nilai rata-rata kelas 62,30 dengan nilai tertinggi 100 dan nilai terendah 20. Perolehan ini menunjukkan peningkatan jika dibandingkan dengan perolehan nilai rata-rata pada pembelajaran awal yaitu 54,61. Perolehan nilai pada siklus I dapat dilihat pada tabel berikut.

Tabel 2. Hasil Evaluasi Siswa dalam Pembelajaran Bahasa Indonesia kelas IV SDN Jatiroke I

\begin{tabular}{|c|c|c|c|c|c|}
\hline \multirow[b]{3}{*}{ No. } & \multirow[b]{3}{*}{ Nama } & \multicolumn{4}{|c|}{ Hasil } \\
\hline & & \multicolumn{2}{|c|}{ Tes Lisan } & \multicolumn{2}{|c|}{ Tes Tertulis } \\
\hline & & $\bar{\zeta}$ & $\frac{\bar{n}}{\bar{z}}$ & $\begin{array}{l}\overline{0} \\
3 \\
\end{array}$ & $\frac{-}{\frac{n}{\bar{x}}}$ \\
\hline 1 & Candra Irawan & $\mathrm{D}$ & $D$ & 20 & 20 \\
\hline 2 & Mena Risna & $\mathrm{D}$ & $D$ & 20 & 40 \\
\hline 3 & Syaeful Anwar D. & $D$ & C & 40 & 40 \\
\hline 4 & Ade Wawan S. & $\mathrm{D}$ & C & 40 & 40 \\
\hline 5 & Agung Setiawan & $\mathrm{D}$ & C & 40 & 60 \\
\hline 6 & Achmad Lathif & $D$ & C & 40 & 40 \\
\hline 7 & Ahmad Sopian & $\mathrm{D}$ & $D$ & 40 & 40 \\
\hline 8 & Ai Mulyanah & $D$ & C & 40 & 40 \\
\hline 9 & $\begin{array}{l}\text { Ajang } \\
\text { Burhanudin }\end{array}$ & C & B & 60 & 80 \\
\hline 10 & Akbar Komara & $\mathrm{B}$ & $\mathrm{B}$ & 80 & 80 \\
\hline 11 & Alfira Lupita R. & B & B & 80 & 80 \\
\hline 12 & Anggi Andini & $\mathrm{B}$ & B & 80 & 100 \\
\hline 13 & Anisa Sufia L. & B & B & 100 & 100 \\
\hline 14 & $\begin{array}{l}\text { Annisa } \\
\text { Nurhidayanti }\end{array}$ & $\mathrm{B}$ & B & 80 & 100 \\
\hline 15 & Azi Wisnu & $\mathrm{D}$ & C & 40 & 60 \\
\hline 16 & $\begin{array}{l}\text { Dadang } \\
\text { Hermawan }\end{array}$ & $\mathrm{D}$ & $\mathrm{D}$ & 40 & 60 \\
\hline 17 & Dalih Purwanto & $\mathrm{D}$ & C & 40 & 60 \\
\hline 18 & Deriski Surya Putri & C & B & 60 & 80 \\
\hline 19 & Dewi Daliah & C & C & 60 & 80 \\
\hline 20 & Diana Wopita & C & B & 60 & 60 \\
\hline 21 & Diki Purnama & $\mathrm{D}$ & C & 40 & 40 \\
\hline 22 & Ega Nurhayati & $\mathrm{B}$ & $\mathrm{B}$ & 80 & 80 \\
\hline 23 & Fajar Fadillah $\mathrm{H}$. & C & B & 80 & 80 \\
\hline 24 & Imer Sulistiya & B & B & 80 & 80 \\
\hline 25 & Jajang Suhendar & $\mathrm{D}$ & C & 40 & 40 \\
\hline 26 & $\begin{array}{l}\text { Johan Taufik } \\
\text { Fauzan }\end{array}$ & $\mathrm{D}$ & C & 40 & 40 \\
\hline & Jumlah & & & 1420 & 1620 \\
\hline & ata-rata Kelas & & & 54,61 & 62,30 \\
\hline & Nilai Tertinggi & B & B & 100 & 100 \\
\hline & Nilai Terendah & D & D & 20 & 20 \\
\hline
\end{tabular}


Asiah, Pendekatan Komunikatif dalam Pembelajaran Bahasa...

Dari data di atas, dapat dijelaskan beberapa hal berkaitan dengan hasil tes lisan dan tulisan yang diperoleh sebagai berikut ini. Data nilai tes lisan pada siklus I, memiliki nilai tertinggi $B$ artinya bagus, dan nilai terendahnya D artinya masih kurang. Sementara itu dari hasil tes tertulis pada siklus I, diketahui bahwa nilai tertinggi 100 dan nilai terendahnya hanya sampai 20.

Tabel 3. Hasil Evaluasi Tertulis Secara Kuantitatif Kelas IV SDN Jatiroke I

\begin{tabular}{|c|c|c|c|c|c|}
\hline \multirow[b]{2}{*}{ No. } & \multirow[b]{2}{*}{ Nilai } & \multicolumn{2}{|c|}{ Jumlah Siswa } & \multicolumn{2}{|c|}{ Persentase } \\
\hline & & 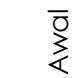 & $\frac{n}{\vec{z}}-$ & $\sum_{\frac{\alpha}{\alpha}}^{\overline{0}}$ & $\frac{n}{\vec{z}}-$ \\
\hline 1. & 100 & 1 & 3 & 3,46 & 11,53 \\
\hline 2. & 80 & 7 & 8 & 26,92 & 30,76 \\
\hline 3. & 60 & 4 & 5 & 15,38 & 19,23 \\
\hline 4. & 40 & 12 & 9 & 46,15 & 34,61 \\
\hline 5. & 20 & 2 & 1 & 7,69 & 3,46 \\
\hline 6. & 0 & - & - & - & - \\
\hline \multicolumn{2}{|c|}{ Jumlah siswa } & 26 & 26 & & \\
\hline \multicolumn{2}{|c|}{ Rata - rata } & 54,61 & 62,30 & & \\
\hline \multicolumn{2}{|c|}{\begin{tabular}{|l|} 
Tuntas (\%) \\
\end{tabular}} & 46,15 & 61,53 & & \\
\hline \multicolumn{2}{|c|}{ Belum Tuntas (\%) } & 53,84 & 38,46 & & \\
\hline
\end{tabular}

Dari data di atas diketahui hasil tes atau hasil evaluasi tulisan yang diperoleh pada siklus I, bahwa jumlah siswa yang mencapai nilai di atas KKM atau tuntas sebayak 16 siswa (61,53\%), sedangkan nilai di bawah KKM atau belum tuntas sebanyak 14 siswa $(38,46 \%)$.

Tabel 4. Hasil Evaluasi Lisan Secara Kualitatif Kelas IV SDN Jatiroke I

\begin{tabular}{|c|l|c|c|}
\hline \multirow{2}{*}{ No } & \multirow{2}{*}{ Nilai } & \multicolumn{2}{|c|}{ Jumlah Siswa } \\
\cline { 3 - 4 } & & Awal & Siklus I \\
\hline 1. & A & - & - \\
\hline 2. & B & 7 & 11 \\
\hline 3. & C & 5 & 11 \\
\hline 4. & D & 14 & 4 \\
\hline Jumlah siswa & 26 & 26 \\
\hline Nilai tertinggi & B & B \\
\hline Nilai terendah & D & D \\
\hline
\end{tabular}

Dari Tabel 4 diketahui hasil tes lisan yang pada siklus I mencakup range nilai tertinggi B, dan nilai terendah D.

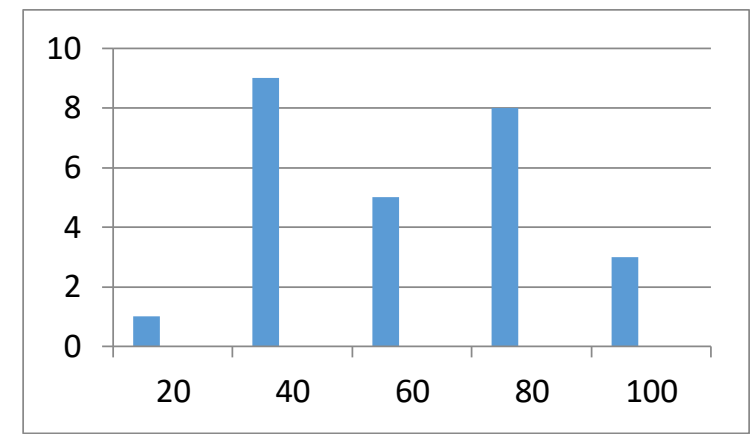

Diagram 1. Nilai Siklus I

Diagram 1 di atas menunjukkan hasil evaluasi berikut ini:

Nilai 20 di Siklus I dari 3,46\% (1 siswa). Nilai 40 di Siklus I dari 34,61\% (9 siswa). Nilai 60 di Siklus I dari 19,23\% (5 siswa). Nilai 80 di Siklus I dari 30,76\% (8 siswa). Nilai 100 di Siklus I dari 11,53\% (3 siswa).

\section{Analisis}

Berdasarkan deskripsi yang sudah dipaparkan, ditemukan beberapa hal penting yang perlu dianalisis. Temuan pertama, pada tahap awal pembelajaran siswa ragu-ragu untuk menjawab pertanyaan guru bahkan tidak ada yang berani untuk bertanya. Lalu temuan kedua, pada kegiatan inti diketahui bahwa pada saat dilakukan percakapan di depan kelas, siswa malu-malu atau kurang tampak keberaniannya. Ada pula siswa yang kesulitan berbicara dengan menggunakan bahasa Indonesia, karena bahasa yang biasa digunakan sehariharinya adalah bahasa Sunda. 
Pada saat mengerjakan soal evaluasi siswa mengalamu kesulitan dalam menjawab pertanyaan soal cerita dan masih ada yang bekerjasama bahkan mencontek pekerjaan temannya. Akibatnya sebanyak 10 orang siswa memperoleh nilai di bawah KKM atau $38,07 \%$ siswa yang belum tuntas. Meskipun sebanyak 10 siswa memperoleh nilai di bawah KKM, namun secara keseluruhan pembelajaran siklus I telah berhasil meningkatkan hasil belajar siswa. Indikator peningkatan tersebut dapat dilihat dari perolehan rata-rata nilai akhir yang mengalami peningkatan dari 54,61 menjadi 62,30.

\section{Refleksi}

Berdasarkan hasil analisis, secara keseluruhan pembelajaran pada siklus I cukup berhasil. Indikator keberhasilan tersebut adalah perolehan nilai rata-rata kelas yang meningkat. Perolehan nilai rata-rata dan cara anak tampil di depan kelas didukung oleh pendekatan komunikatif dengan bermain peran. Namun demikian ada beberapa hal yang harus diperbaiki agar pembelajaran pada siklus II memperoleh hasil yang lebih baik, antara lain sebagai berikut.

1. Motivasi guru harus menyentuh secara merata terutama pada siswa yang malu-malu atau kurang keberaniannya tampil di depan kelas.

2. Dalam pelaksaan berbicara di depan kelas terutama bagi siswa yang kesulitan untuk berbicara menggunakan bahasa Indonesia harus terus dilatih.

Berdasarkan hasil refleksi tersebut, maka tindakan selanjutnya yang akan diberikan pada siklus II adalah materi mengenai penyampaikan pesan yang diterima melalui telepon.

\section{Siklus II}

\section{Deskripsi}

Pembelajaran siklus II dilaksanakan pada pertemuan berikutnya dan dihadiri oleh seluruh siswa yang berjumlah 26 orang. Indikator yang dipelajari pada siklus II adalah menyampaikan pesan yang diterima melalui telepon sesuai dengan isi pesan, lafal dan intonasi yang tepat. Setting pembelajaran siklus II dilakukan sesuai dengan RPP. Berdasarkan pengamatan peneliti konsentrasi dan antusias siswa terpusat pada pelajaran karena siswa merasa termotivasi dengan melihat contoh dialog yang terpampang di papan tulis.

Pada awal pembelajaran siswa menjawab pertanyaan awal yang diajukan dengan penuh antusias. Selanjutnya, kegiatan yang berlangsung pada tahap ini berjalan cukup lancar.

Pada kegiatan inti siswa diberi keleluasaan berpasangan dengan siapa yang disukainya untuk melaksanakan percakapan di depan kelas. Seluruh siswa tampak sangat antusias dan melakukan percakapan dengan penuh kegembiraan. 
Berdasarkan hasil observasi siswa telah mampu menyampaikan percakapan dengan lafal dan intonasi yang tepat. Setelah kegiatan eksplorasi dan elaborasi selesai dilakukan, selanjutnya tahap evaluasi, siswa mampu mengerjakan soal secara mandiri peneliti tidak menemukan satu siswa pun yang mencontek atau bekerjasama dengan temannya. Siswa lebih terampil dalam menyampaikan pesan yang diterima dengan menggunakan bahasa Indonesia yang baik dan benar.

Perolehan nilai rata-rata kelas untuk hasil belajar adalah 80 dengan nilai tertinggi 100 dan nilai terendah 40. Sementara perolehan nilai secara lisan termasuk dalam rata-rata yang baik. Perolehan nilai tersebut bisa dilihat secara lengkap pada Tabel 5 sebagai berikut.

Tabel 5. Hasil Evaluasi Siswa dalam Pembelajaran Bahasa Indonesia Kelas IV SDN Jatiroke I

\begin{tabular}{|c|c|c|c|c|c|c|c|}
\hline \multirow[b]{3}{*}{ No } & \multirow[b]{3}{*}{ Nama } & \multicolumn{6}{|c|}{ Hasil } \\
\hline & & \multicolumn{3}{|c|}{ Tes Lisan } & \multicolumn{3}{|c|}{ Tes Tertulis } \\
\hline & & 官 & $\frac{\bar{n}}{\bar{s}}$ & $\begin{array}{l}\overline{\bar{n}} \\
\frac{2}{5}\end{array}$ & 家 & $\frac{\bar{n}}{\bar{n}}$ & $\begin{array}{l}= \\
\bar{n} \\
\frac{\bar{y}}{\bar{n}}\end{array}$ \\
\hline 1 & $\begin{array}{l}\text { Candra } \\
\text { Irawan }\end{array}$ & $D$ & $D$ & $\mathrm{D}$ & 20 & 20 & 40 \\
\hline 2 & Mena Risna & $\mathrm{D}$ & $D$ & $C$ & 20 & 40 & 60 \\
\hline 3 & $\begin{array}{l}\text { Syaeful } \\
\text { Anwar D. }\end{array}$ & D & C & B & 40 & 40 & 60 \\
\hline 4 & $\begin{array}{l}\text { Ade Wawan } \\
\text { S. }\end{array}$ & D & C & B & 40 & 40 & 80 \\
\hline 5 & $\begin{array}{l}\text { Agung } \\
\text { Setiawan }\end{array}$ & D & C & B & 40 & 60 & 80 \\
\hline 6 & $\begin{array}{l}\text { Achmad } \\
\text { Lathif }\end{array}$ & D & C & $B$ & 40 & 40 & 80 \\
\hline 7 & $\begin{array}{l}\text { Ahmad } \\
\text { Sopian }\end{array}$ & D & D & C & 40 & 40 & 60 \\
\hline 8 & Ai Mulyanah & D & C & B & 40 & 40 & 60 \\
\hline 9 & $\begin{array}{l}\text { Ajang } \\
\text { Burhanudin }\end{array}$ & C & B & A & 60 & 80 & 100 \\
\hline
\end{tabular}

\begin{tabular}{|c|c|c|c|c|c|c|c|}
\hline 10 & $\begin{array}{l}\text { Akbar } \\
\text { Komara }\end{array}$ & B & $B$ & $A$ & 80 & 80 & 100 \\
\hline 11 & $\begin{array}{l}\text { Alfira Lupita } \\
\text { R. }\end{array}$ & B & B & $A$ & 80 & 80 & 100 \\
\hline 12 & Anggi Andini & B & B & $A$ & 80 & 100 & 100 \\
\hline 13 & Anisa Sufia L. & $B$ & $B$ & $A$ & 100 & 100 & 100 \\
\hline 14 & $\begin{array}{l}\text { Annisa } \\
\text { Nurhidayanti }\end{array}$ & B & B & $A$ & 80 & 100 & 100 \\
\hline 15 & Azi Wisnu & $\mathrm{D}$ & $\mathrm{C}$ & $B$ & 40 & 60 & 80 \\
\hline 16 & $\begin{array}{l}\text { Dadang } \\
\text { Hermawan }\end{array}$ & $D$ & $\mathrm{D}$ & C & 40 & 60 & 80 \\
\hline 17 & $\begin{array}{l}\text { Dalih } \\
\text { Purwanto } \\
\end{array}$ & $D$ & C & $B$ & 40 & 60 & 80 \\
\hline 18 & $\begin{array}{l}\text { Deriski Surya } \\
\text { Putri }\end{array}$ & C & B & B & 60 & 80 & 80 \\
\hline 19 & Dewi Daliah & C & C & B & 60 & 80 & 80 \\
\hline 20 & Diana Wopita & C & $B$ & $B$ & 60 & 60 & 80 \\
\hline 21 & Diki Purnama & $\mathrm{D}$ & $\mathrm{C}$ & $B$ & 40 & 40 & 60 \\
\hline 22 & $\begin{array}{l}\text { Ega } \\
\text { Nurhayati }\end{array}$ & B & $B$ & $A$ & 80 & 80 & 100 \\
\hline 23 & $\begin{array}{l}\text { Fajar Fadillah } \\
\text { H. }\end{array}$ & C & B & B & 80 & 80 & 80 \\
\hline 24 & Imer Sulistiya & $\mathrm{B}$ & $\mathrm{B}$ & A & 80 & 80 & 100 \\
\hline 25 & $\begin{array}{l}\text { Jajang } \\
\text { Suhendar }\end{array}$ & $D$ & C & B & 40 & 40 & 80 \\
\hline 26 & $\begin{array}{l}\text { Johan Taufik } \\
\text { Fauzan }\end{array}$ & $\mathrm{D}$ & C & B & 40 & 40 & 60 \\
\hline & Jumlah & & & & 1420 & 1620 & 2080 \\
\hline \multicolumn{2}{|c|}{ Rata-rata Kelas } & & & & 54,61 & 62,30 & 80 \\
\hline \multicolumn{2}{|c|}{ Nilai Tertinggi } & B & B & A & 100 & 100 & 100 \\
\hline \multicolumn{2}{|c|}{ Nilai Terendah } & D & D & $C$ & 20 & 20 & 40 \\
\hline
\end{tabular}

Berdasarkan data pada Tabel 5 di atas diketahui hasil tes lisan yang diperoleh pada siklus 1 memiliki range dengan nilai tertinggi B artinya bagus, sedangkan nilai terendahnya $D$ artinya kurang. Kemudian pada siklus II, nilai tertingginya A artinya sangat baik, dan nilai terendahnya D yang artinya kurang. Hasil tes tertulis pada siklus I, diketahui nilai tertinggi 100 dan nilai terendah 20. Lalu pada siklus II, diketahui nilai tertinggi 100 dan nilai terendah 40 .

Berikutnya, berkaitan dengan hasil evaluasi tertulis pelajaran bahasa Indonesia secara kuantitatif kelas IV SDN Jatiroke I, disajikan pada Tabel 6. 
Dari Tabel 6 diketahui hasil tes tertulis yang diperoleh pada siklus I, nilai di atas KKM ada 16 siswa atau $61,53 \%$. Sedangkan nilai di bawah KKM ada 14 siswa atau $38,46 \%$. Lalu pada siklus II, nilai di atas KKM ada 25 siswa atau 96,15\%, dan nilai di bawah KKM ada 1 siswa atau $3,46 \%$.

Tabel 6. Hasil Evaluasi Tertulis Secara Kuantitatif Kelas IV SDN Jatiroke I

\begin{tabular}{|c|c|c|c|c|c|c|}
\hline \multirow[b]{2}{*}{ Nilai } & \multicolumn{3}{|c|}{ Jumlah Siswa } & \multicolumn{3}{|c|}{ Persentase } \\
\hline & 㞼 & $\frac{\stackrel{\infty}{3}}{\frac{5}{5}}$ & 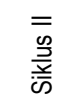 & 裉 & 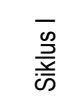 & 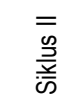 \\
\hline 100 & 1 & 3 & 8 & 3,46 & 11,53 & 30,76 \\
\hline 80 & 7 & 8 & 11 & 26,92 & 30,76 & 42,30 \\
\hline 60 & 4 & 5 & 6 & 15,38 & 19,23 & 23,07 \\
\hline 40 & 12 & 9 & 1 & 46,15 & 34,61 & 3,46 \\
\hline 20 & 2 & 1 & - & 7,69 & 3,46 & - \\
\hline 0 & - & - & - & - & - & - \\
\hline $\begin{array}{l}\text { Jumlah } \\
\text { siswa }\end{array}$ & 26 & 26 & 26 & & & \\
\hline Rata-rata & 54,61 & 62,30 & 80 & & & \\
\hline Tuntas (\%) & 46,15 & 61,53 & 96,1 & & & \\
\hline
\end{tabular}

\begin{tabular}{|c|c|c|c|c|c|c|}
\hline & & & 5 & & & \\
\hline $\begin{array}{c}\text { Belum } \\
\text { Tuntas (\%) }\end{array}$ & 53,84 & 38,46 & 3,46 & & & \\
\hline
\end{tabular}

Tabel 7. Hasil Evaluasi Lisan Secara Kualitatif Kelas IV SDN Jatiroke I

\begin{tabular}{|c|c|c|c|}
\hline & \multicolumn{3}{|c|}{ Jumlah Siswa } \\
\hline Nilai & Awal & Siklus I & Siklus II \\
\hline A & - & - & 8 \\
\hline B & 7 & 11 & 14 \\
\hline C & 5 & 11 & 3 \\
\hline D & 14 & 4 & 1 \\
\hline Jumlah siswa & 26 & 26 & 26 \\
\hline Nilai tertinggi & B & B & A \\
\hline Nilai terendah & D & D & D \\
\hline
\end{tabular}

Dari data di atas diketahui hasil tes atau hasil evaluasi lisan yang diperoleh pada siklus I, yakni nilai tertinggi dan nilai terendah D. Sementara itu, pada siklus II diketahui capaian nilai tertinggi adalah $\mathrm{A}$, sedangkan nilai terendahnya masih D.

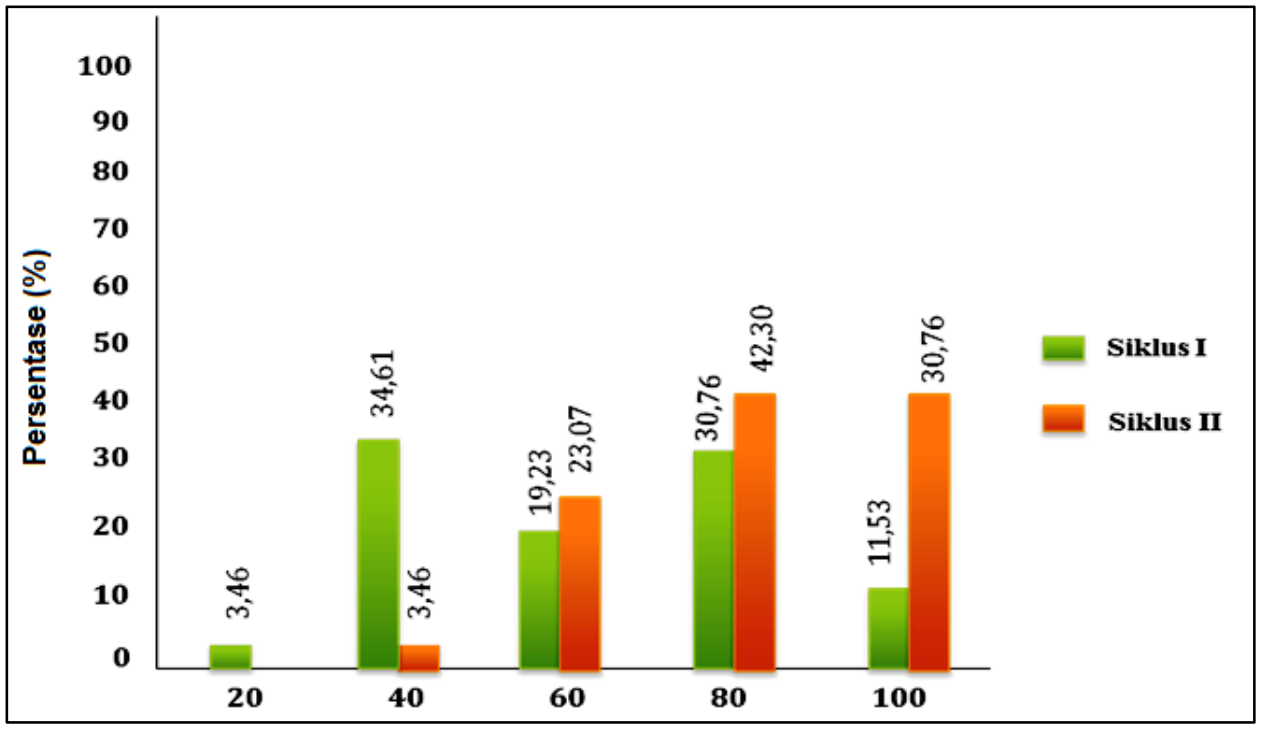

Diagram 2. Nilai Siklus I dan Siklus II

Diagram di atas memperlihatkan adanya peningkatan dari setiap siklus. Nilai 20 di siklus I dari 3,46\% (1 siswa) dan di Siklus II tidak ada. Nilai 40 di siklus I dari 34,61\% (9 siswa) dan di siklus II 3,46\% (1 siswa). Nilai 60 di siklus I dari 19,23\% (5 siswa) dan di siklus II $23,07 \%$ (6 siswa). Nilai 80 di Siklus I dari $30,76 \%$ (8 siswa) dan di siklus I| 42,30\% (11 
Asiah, Pendekatan Komunikatif dalam Pembelajaran Bahasa...

siswa). Nilai 100 di siklus I dari 11,53\% (3 siswa) dan di siklus II 30,76\% (8 siswa).

\section{Analisis}

Temuan pertama pada tahap awal pembelajaran adalah siswa sudah memiliki pengetahuan awal mengenai konsep penyampaian pesan melalui telepon, hal ini menunjukkan pebelajaran pada siklus II sudah berhasil dalam meningkatkan keterampilan berbicara siswa di depan kelas untuk menyampaikan pesan yang diterimanya melalui telepon. Pengetahuan awal siswa sangat berpengaruh pada hasil belajar dan keterampilan berbicara karena menurut Solchan, dkk. (2001, p. 6.41), pendekatan komunikatif dalam pembelajaran bahasa sering diasosiasikan dengan silabus. Pemilihan materi silabus itu sendiri tidak didasarkan pada tingkat kesukaran dan kerumitan butir struktur, tetapi didasarkan pada kebutuhan pembelajar. Dengan demikian, analisis kebutuhan merupakan kebutuhan yang mutlak.

Memasuki kegiatan inti pembelajaran siswa terlihat antusias dan penuh dengan kegembiraan saat melaksanakan percakapan dengan bermain peran di depan kelas dengan teman yang disukainya. Berdasarkan hasil analisis terhadap perolehan nilai hasil belajar dan keterampilan siswa dalam berbicara dapat disimpulkan pembelajaran pada siklus II telah berhasil. Hal ini dapat dilihat dari perolehan nilai rata-rata hasil belajar siswa yang meningkat dari 62,30 menjadi
80 pada siklus II, selain itu nilai terkecil yang diperoleh pada siklus ini adalah 40. Siswa yang belum tuntas ada 1 orang itu karena siswa tersebut membutuhkan perhatian khusus.

\section{Refleksi}

Berdasarkan hasil analisis terhadap hasil belajar siklus | dan siklus || disimpulkan bahwa pembelajaran pada kedua siklus tersebut telah meningkat secara signifikan. Dilihat dari hasil evaluasi secara lisan maupun secara tulisan. Siklus I dari 26 siswa yang mendapat nilai di atas atau sama dengan KKM ada 16 siswa (61,53\%) dengan rata-rata kelas 62,30 naik di Siklus II menjadi 25 siswa $(96,15 \%)$ dengan ratarata kelas 80 . Kemajuan tersebut berkat penyampaian materi secara terencana disertai dengan pendekatan komunikatif. Hal tersebut membuat siswa aktif, termotivasi dan meningkatnya keterampilan berbicara siswa di kelas IV untuk menyampaikan pesan yang diterima melalui telepon sesuai dengan isi pesan.

\section{PEMBAHASAN}

Nilai pada siklus I sudah mengalami peningkatan, meskipun belum cukup memuaskan. Hasil perolehan siswa yang mencapai KKM sebanyak 16 siswa atau $61,53 \%$ dengan rata-rata kelas 62,30 . Peningkatan ini dapat dikatakan sebagai efek dari pendekatan komunikatif dalam pembelajaran Bahasa Indonesia. Oleh karena itu, materi diulang kembali dan diperluas, dengan tetap mengikuti alur 
materi yang dikemukakan oleh Febicahyanti, dkk. (2006) serta Warsidi \& Farika (2009).

Selama siklus I dilaksanakan, terdapat beberapa kelebihan/kekuatan dan kekurangan/kelemahan yang berhasil dianalisis.

1. Kekuatan dalam pembelajaran:

a. Memberikan arahan atau petunjuk cara-cara melakukan percakapan secara berpasangan.

b. Memberikan bimbingan terhadap pelaksanaan percakapan di depan kelas.

2. Kelemahan dalam pembelajaran:

a. Motivasi guru kurang menyentuh secara merata terutama pada siswa yang malu-malu atau yang kurang keberaniannya tampil ke depan kelas.

b. Dalam pelakasanaan berbicara di kelas, kalau sudah diminta dengan jelas masih ada siswa yang kesulitan untuk berbicara.

c. Hasil evaluasi siswa masih belum memuaskan.

Pada siklus II penyampaian materi pembelajaran menggunakan pendekatan komunikatif dan diperjelas dengan pelaksanaan bermain peran (role playing) sehingga peserta didik terlihat lebih aktif dalam belajar dan termotivasi terlihat dari hasil evaluasi ada peningkatan yang signifikan. Alasan mengapa bermain peran dipadukan dengan pendekatan komunikatif, mengingat bahwa kegiatan bermain peran dapat menguatkan sisi komunikasi yang dilkukan oleh siswa yang memerakan karena dapat lebih memaknainya, di samping memang bermain peran ini merupakan kegiatan yang menyenangkan juga (Santrock, 2007).

Beberapa kekuatan dan kelemahan yang dapat ditemukan dalam siklus II, antara lain sebagai berikut ini.

1. Kekuatan

a. Guru melaksanakan pembelajaran dengan menggunakan pendekatan komunikatif bermain peran dalam pembelajaran Bahasa Indonesia yang dipajangkan dalam situasi komunikasi nyata yang tujuannya untuk mengembangkankemampuan siswa berkomunikasi.

b. Dalam pelaksanaan berbicara di kelas, siswa tanpa diminta guru sudah berani ke depan kelas secara berpasangan melakukan percakapan dengan lafal, intonasi yang tepat dan suara yang jelas.

c. Guru memberikan bimbingan dan motivasi terhadap pelaksanaan pembelajaran sehingga hasil tes lisan dan tulisan memuaskan.

\section{Kelemahan}

Masih ada satu siswa yang mendapat nilai di bawah rata-rata kelas dan cara bicara pun masih belum sesuai dengan konteks. 
Asiah, Pendekatan Komunikatif dalam Pembelajaran Bahasa...

Proses perbaikan pembelajaran Bahasa Indonesia Siklus I dan Siklus || dengan penerapan komunikatif menunjukkan hasil yang baik dilihat dari keaktifan, motivasi dan keberanian siswa tampil di depan kelas untuk menyampaikan pesan yang diterima melalui telepon sesuai dengan isi pesan. Dari hasil tersebut, dapat dikatakan bahwa dengan pendekatan komunikatif dalam pembelajaran Bahasa Indonesia dapat meningkatkan keterampilan berbicara siswa di kelas IV SDN Jatiroke I. Peningkatan keterampilan berbicara ini tidak lepas dari efektivitas pendekatan komunikatif yang lebih menekankan pada bagaimana materi diajarkan sesuai dengan kebutuhan siswa (Solchan, dkk., 2001) dan juga pemaduan kegiatan bermain peran di dalam pendekatan tersebut, yang menurut pendapat VanFleet (2001) dan Santrock (2007), bermain peran akan turut mengembangkan potensi siswa yang dilibatkan di dalamnya.

\section{SIMPULAN}

Berdasarkan hasil perbaikan pembelajaran yang dilakukan melalui PTK, pada pembelajaran Bahasa Indonesia yang dilaksanakan 2 siklus dapat disimpulkan bahwa pendekatan komunikatif dapat meningkatkan keterampilan berbicara siswa di depan kelas. Hal ini dapat dilihat dari siklus I dan II selama perbaikan. Sebelum dilakukan tindakan siswa yang terlibat aktif dan yang mendapat nilai di atas KKM atau sama dengan KKM 60 dari jumlah 26 siswa hanya
12 siswa (46,15\%). Pada Siklus I siswa yang aktif dan berani tampil di depan kelas serta yang telah mencapai ketuntasan 16 siswa (61,53\%). Pada Siklus II meningkat secara signifikan siswa yang mencapai ketuntasan 25 siswa $(96,15 \%)$ dengan ratarata kelas 80 . Secara keseluruhan dalam pelaksanaan berbicara di kelas siswa sangat termotivasi sehingga berani tampil di depan kelas tanpa disuruh guru dan keterampilan berbicara pun meningkat.

\section{REFERENSI}

Febicahyanti, E., dkk. (2006). Panduan pembelajaran bahasa Indonesia kelas IV. Bandung: CV. Thursina.

Mulyasa, E. (2009). Praktik penelitian tindakan kelas. Bandung: PT Remaja Rosdakarya.

Peraturan Pemerintah Nomor 19 Tahun 2005 tentang Standar Nasional Pendidikan.

Santrock, J. W. (2007). Psikologi pendidikan (edisi ke-2). Jakarta: Prenada Media Grup.

Solchan, T. W., dkk. (2001). Hakikat pendekatan prosedur, dan strategi pembelajaran bahasa Indonesia berdasarkan pendekatan komunikatif dalam sistem pembelajaran bahasa Indonesia (Modul UT). Jakarta: Pusat Penerbitan UT.

Undang-Undang Republik Indonesia Nomor 20 Tahun 2003 tentang Sistem Pendidikan Nasional.

Valette, R. (1977). Modern language testing. New York: Brace Jovanovich Inc.

VanVleet, R. (2001). A parent's handbook of filial play therapy. Boiling Springs, PA: Play Therapy Press. 
Wardani, I. G. A. K. (2006). Penelitian tindakan kelas. Jakarta: Universitas Terbuka.

Warsidi, E. \& Farika. (2009). Bahasa Indonesia membuatku cerdas (kelas IV). Bandung: Pusat Perbukuan.

Wiriaatmadja, R. (2005). Metode penelitian tindakan kelas. Bandung: PPs UPI bekerjasama dengan PT. Remaja Rosdakarya. 